\section{Radiological and Histopathological Comparison of Microporous Polysaccharide Hemospheres and Oxidized Regenerated Cellulose in the Rabbit Brain: A Study of Efficacy and Safety}

\section{Tavșan Beyninde Mikroporöz Polisakkarit Hemosferler ile Okside Rejenere Sellülozun Radyolojik ve Histopatolojik Olarak Karșılaștırılması: Bir Etkinlik ve Güvenilirlik Calıșması}

\begin{abstract}
AIM: Topical hemostatic agents are widely used in brain surgery but they have some disadvantages such as foreign body reaction, being a focus for infection and causing artifacts in radiological examinations. The purpose of this study is to compare the effectiveness and safety of microporous polysaccharide hemospheres $(\mathrm{MPH})$ with a well known agent, oxidized regenerated cellulose (ORC), histopathologically and radiologically.

MATERIAL and METHODS: Standard brain lesions (4x1mm) were created in 24 hemispheres in $12 \mathrm{New}$-Zealand rabbits. Animals were divided into three groups; control, ORC and MPH. Twenty-four hours later, all rabbits magnetic resonance brain imaging. After imaging, the animals were sacrificed and the brains were removed for histopathological analysis.

RESULTS: Histopathological analysis showed no significant difference between the groups. Radiological examination showed no significant difference between the MPH and ORC groups in terms of edema but the edema in control group was significantly prominent than MPH and ORC groups $(\mathrm{p}<0.001)$.

CONCLUSION: A new agent $(\mathrm{MPH})$ provides safe and effective hemostasis in the brain in this study. The most important advantage of microporous polysaccharide hemospheres is their rapid clearance from the surgical field and therefore having the potential of causing less imaging artifacts.
\end{abstract}

KEYWORDS: Brain hemorrhage, Hemostasis, Magnetic resonance, Microporous polysaccharide hemospheres, Oxidized regenerated cellulose

\section{ÖZ}

AMAÇ: Topikal hemostatik ajanlar beyin cerrahisinde yaygın bir şekilde kullanılmakla birlikte yabancı cisim reaksiyonu, enfeksiyon için odak olușturma ve radyolojik tetkiklerde artefakt oluşturma gibi dezavantajları mevcuttur. $\mathrm{Bu}$ çalışmanın amacı, mikroporöz polisakkarit hemosferler (MPH) ile iyi bilinen bir ajan olan okside rejenere sellülozun (ORC) etkinlik ve güvenilirliklerini histopatolojik ve radyolojik olarak karşılaştırmaktır.

YÖNTEM ve GEREÇ: 12 Yeni Zelanda tavşanında 24 hemisferde standart $(4 \times 1$ $\mathrm{mm}$ ) beyin lezyonları oluşturuldu. Denekler 3 gruba ayrıldı; kontrol, ORC ve $\mathrm{MPH}$. Yirmi dört saat sonra tüm hayvanlara manyetik rezonans görüntüleme yapıldı. Görüntüleme sonrası denekler sakrifiye edildi ve beyinleri histopatolojik analiz için çıkarıldı.

BULGULAR: Histopatolojik analiz gruplar arasında belirgin farklılık göstermedi. Radyolojik incelemede ödem yönünden MPH ve ORC grupları arasında belirgin farklılık izlenmemekle birlikte, kontrol grubunda ödem MPH ve ORC gruplarına gore belirgin bir şekilde yüksek bulundu $(\mathrm{p}<0,001)$.

SONUÇ: Bu çalışmada yeni bir ajan (MPH), beyinde hemostazda güvenilir ve etkin bulunmuştur. MPH'ın en önemli avantajı cerrahi sahadan hızla uzaklaşması ve bu yolla daha az potansiyel görüntüleme artefaktına yol açmasıdır.

ANAHTAR SÖZCÜKLER: Beyin kanaması, Hemostaz, Manyetik rezonans, Mikroporöz polisakkarit hemosfer, Okside rejenere selüloz

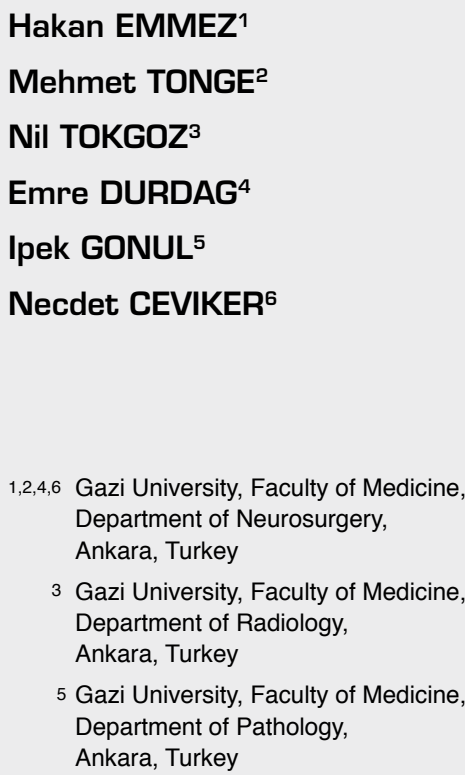

3 Gazi University, Faculty of Medicine, Department of Radiology, Ankara, Turkey

5 Gazi University, Faculty of Medicine Department of Pathology, Ankara, Turkey

Received : 16.07.2010

Accepted : 27.07.2010

Presented in: Turkish Neurosurgical Society, 24th Scientific Congress, 14-18 May, 2010, Antalya, Turkey.

Correspondence address Mehmet TONGE

Phone : +90 3122025116

E-mail : tonge_m@yahoo.com 


\section{INTRODUCTION}

Meticulous hemostasis is a must in all neurosurgical procedures because of potential postoperative hemorrhage and related complications. Gross hemorrhages originating from the vascular bed can be coagulated by bipolar electrocoagulation but controlling oozing hemorrhage within a large surgical field is difficult. Gentle compression with a piece of cotton and continued irrigation is an option for this situation. Recently, topical hemostatic agents have been commonly used in routine practice by neurosurgeons for achieving adequate hemostasis. The most common topical hemostatic agents are gelatin sponge (Gelfoam; Pfizer, New York, NY), oxidized cellulose (Surgicel; Ethicon, Inc., Somerville, NJ), microfibrillar collagen (Avitene; Alcon, Inc., Humacao, PR), and gelatin matrix thrombin sealants (Floseal; Baxter Healthcare Corp., Deerfield, IL).

In patients with brain tumors, early post-operative and follow-up magnetic resonance imaging (MRI) is routinely used to detect the residual and recurrent tumor. Topical hemostatic agents have disadvantages such as mimicking residual and recurrent tumor due to prolonged degradation. Any agent that forms less imaging artifact is therefore more advantageous than others for safely interpreting MRI images. Serving as a focus for infection and having a potential for inducing foreign body reaction are the other side effects of these agents. Topical hemostatic agents may also cause a mass effect and edema (16). Microporous polysaccharide hemospheres (MPH), a new generation hemostatic agent (Arista ${ }^{\mathrm{TM}}$; Medafor Inc, Minneapolis, MN) are derived from plant starch and powder-like agent. Arista was found to be completely resorbable within a couple of minutes and is also effective in hemostasis by accelerating the formation of platelet fibrin mesh within the bleeding surgical bed.

The aim of this study was to compare the effectiveness and safety of two hemostatic agents - oxidized regenerated cellulose (ORC) and microporous polysaccharide hemospheres - via both histopathological and radiological evaluation in an experimental brain hemorrhage model.

\section{MATERIAL and METHODS}

\section{Animals and Surgical procedure}

An experimental brain hemorrhage model previously used by Kaymaz et al. in rabbits was used for this study (9). 12 New Zealand rabbits weighing 2.5-3 kg were used following the Experimental Animals Local Ethics Committee approval. All animals were housed and cared for in separate cages with a $12 \mathrm{hr}$ light-dark cycle at the Experimental Animals Care Center of our institution under veterinary observation. The animals were fed ad libitum and had free access to tap water.

The animals were anaesthetized with an intramuscular injection of Ketamine $\mathrm{HCl} 50 \mathrm{mg} / \mathrm{kg}$ (Ketalar; Parke-Davis, Eczacibasi, İstanbul, Turkey) and Xylazine $5 \mathrm{mg} / \mathrm{kg}$ (Rompun; Bayer, İstanbul, Turkey). Each animal was then positioned prone and a $3 \mathrm{~cm}$ midline cranio-caudal skin incision was made. After dissection of the periosteum, two burr holes were opened at the coronal sutures of the animal bilaterally using an electrical micro drill (Aesculap ELAN-E, Tuttlingen, Germany) under the operative microscope (OPMI 9-FC, Carl Zeiss AG, Germany). The dura was incised gently and a deep parenchymal lesion of $4 \mathrm{~mm}$ length and $1 \mathrm{~mm}$ width was created using an arachnoid knife for achieving diffuse parenchymal bleeding. The animals were divided into three groups. In group-I, only continuous irrigation with isotonic saline solution was performed for hemostasis through a $4 \times 1 \mathrm{~mm}$ cotton piece in both hemispheres. The cotton piece was then removed and hemostasis was observed. In group-II, one layered, $4 \times 2 \mathrm{~mm}$ rectangle-shaped ORC was placed between the bleeding parenchymal faces and irrigated gently with isotonic saline solution through a similar cotton piece for 1 minute. In group-III, microporous polysaccharide hemospheres powder was filled sufficiently between the bleeding parenchymal faces, and the surgical field was then irrigated same as the other groups. In case of inadequate hemostasis, an additional one minute session was performed for all groups at the end of the $1^{\text {st }}$ minute. In the control group, only one surgical field required a second session of hemostasis. After achieving hemostasis, the edges of the dura were only reapproximated without sutures. The overlying skin was closed using 2.0 vicryl sutures.

All animals were anaesthetized again with an intramuscular injection of Ketamine $\mathrm{HCl} 50 \mathrm{mg} / \mathrm{kg}$ (Ketalar; Parke-Davis, Eczacıbaşı, İstanbul, Turkey) and Xylazine $5 \mathrm{mg} / \mathrm{kg}$ (Rompun; Bayer, İstanbul, Turkey) at the post-operative $24^{\text {th }}$ hour and underwent a magnetic resonance brain imaging. After imaging, the animals were sacrificed using Pentobarbital 100 
$\mathrm{mg} / \mathrm{kg}$ iv. (Pental Sodyum; I.E. Ulagay, Istanbul, Turkey). The brains were then immediately removed and fixed in formaldehyde.

\section{Histopathological examination:}

The harvested brain tissues were fixed in 10\% buffered formaldehyde for 24 hours and sampled totally. Following routine tissue processing, $4 \mu \mathrm{m}$ sections were cut and stained with hematoxylineosin (H\&E). Histopathological examination was performed under light microscopy. The presence of hemorrhage, pericellular edema, inflammation, residual hemostatic agent and neuronal degeneration was evaluated by a pathologist who was blinded to the groups. The nature (whether polymorphonuclear or mononuclear) and location (whether perivascular or parenchymal) of inflammatory cells were also noted.

Histopathological examination results of the specimens are shown in Figure 1. The following parameters were investigated in each specimen: hemorrhage, inflammation, pericellular edema, and neuronal degeneration. All parameters were graded as 0: None; 1: Mild; 2: Significant. The sum of the points was divided into the number of subjects within each group, providing the arithmetical mean value.

\section{Radiological Examination:}

MRI was performed using a 1.5 Tesla superconducting MR unit (Signa Excite; GE Medical Systems, Milwaukee, WI, USA). Rabbits were positioned prone and a head coil was used. MRI was performed in the coronal plane and included T1-weighted $(\mathrm{T} 1 \mathrm{~W})(\mathrm{TR} / \mathrm{TE} / \mathrm{NEX}=600 / 20 / 6)$ and T2-weighted (T2W) $(4500 / 112 / 4)$ images with a slice thickness of $2 \mathrm{~mm}$ and a slice interval of zero. For volumetric analyses, the Short Tau Inversion Recovery Sequence (STIR) (TR/TE/Inversion time/ $\mathrm{NEX}=5560 / 40 / 170 / 7)$ with a $2 \mathrm{~mm}$ slice thickness and no interslice gap was performed in a coronal plane. In all MR sequences the field of view was $8 \times 6 \mathrm{~cm}$. The imaging matrix was $256 \times 160$ on T1W imaging, and it was $256 \times 192$ on T2W and STIR sequences. Qualitative and quantitative evaluations were made by a neuro-radiologist blinded to the location of each type of hemostatic agent and the control group. On MRI, edema appears hypointense on T1W and hyperintense on T2W images. To perform volumetric analysis of the area of edema, images were transferred to a workstation. The region of interest was drawn and the volume was measured on the workstation. These procedures were repeated three times and mean volumes were calculated. The measurements of all subjects were performed by the same experienced neuro-radiologist $(9,17)$. Qualitative evaluation was done on T1W, T2W, and inversion recovery $\mathrm{T} 2 \mathrm{~W}$ sequences. Parenchymal distortion was graded as "none", "minimal (Grade 1)" or "prominent (Grade 2)".

\section{Statistical Analysis:}

Histopathological data recorded during the experiment were analyzed using SPSS version 15.0 software for Windows. Both radiological and histopathological data were documented and evaluated. "Levene's test for equality of variances" was performed for determining the homogeneity of each group. The " $t$ test" for equality of means was then used to evaluate the differences between independent samples for assessment of radiological variables. The Kruskal-Wallis variance test for nonparametric data was used for comparing differences between the groups. Where analysis of variance showed significant differences, the Mann Whitney-U test was applied to determine the source of the difference. Significance was approved when $\mathrm{P}$ values were less than 0.05 .

\section{RESULTS}

\section{Histopathological Examination:}

There was no significant difference between the groups in terms of hemorrhage, inflammation, pericellular edema, and neuronal degeneration. However, inflammation was slightly higher in $\mathrm{MPH}$

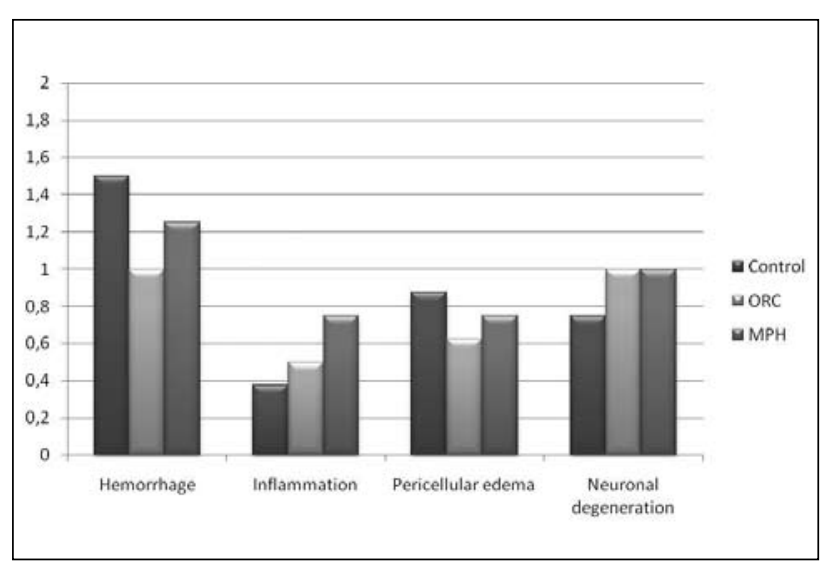

Figure 1: Graph showing histopathological parameters (hemorrhage, inflammation, pericellular edema and neuronal degeneration) graded between 0 and 2 under light microscopy. 
group than the control and ORC groups, and the hemorrhage was more marked in the control group (Figure 1). The polymorphonuclear leucocytes were prominent in all groups. Hemostatic agent was visible in all specimens in the ORC group, but no residual or foreign material was observed in both the control and MPH groups (Figure 2A,B,C).

\section{MRI:}

The early effects of MPH and ORC on lesioned rabbit brain parenchyma were investigated. The signal intensity of the edema was hypointense on $\mathrm{T} 1 \mathrm{~W}$, and hyperintense on $\mathrm{T} 2 \mathrm{~W}$ and inversion recovery $\mathrm{T} 2 \mathrm{~W}$ images (Figure $3 \mathrm{~A}, \mathrm{~B}$ ). Although the volume of edema was larger in the $\mathrm{MPH}$ group than the ORC group in all surgical fields, this was not statistically significant $(\mathrm{p}=0.512)$. The volume of edema was larger than the MPH or ORC groups $(p<0.001)$ in all surgical fields in the control group. The mean volumes are shown in Figure 4.
Parenchymal distortion was seen in 3 of 8 surgical fields $(37.5 \%)$ in the ORC group. In two of them it was Grade 1, and in one of the others it was Grade 2. The parenchymal distortion was detected in all surgical fields in the MPH and control groups. There were five Grade 1, three Grade 2 distortion cases in the MPH group and four Grade 1, four Grade 2 distortion cases in the control group (Figure 5). Intraparenchymal air was noted in one surgical field in the control group.

\section{DISCUSSION}

Inadequate hemostasis has the risk of potential complications in any surgical intervention but these complications may be devastating in neurosurgery. Neurosurgeons routinely use bipolar electrocautery and slight manual pressure for hemostasis. Another way of hemostasis is using topical hemostatic agents, which are increasing in number and widely used. The main goals of an optimal hemostatic agent used

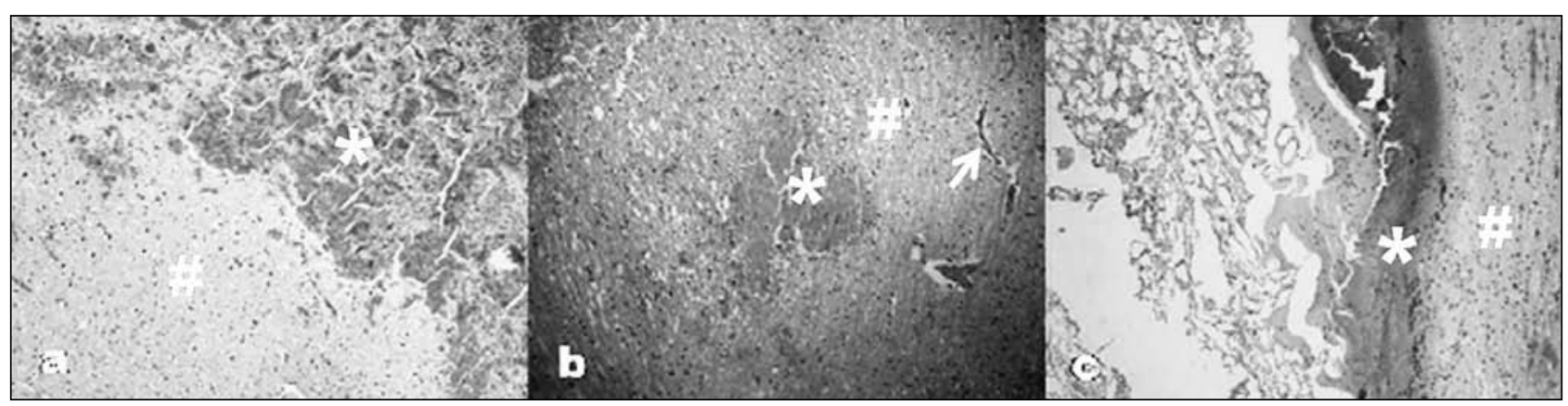

Figure 2: Histopathological examination of the groups under light microscopy. (Hematoxylene - Eosin, 200x) (A) Control; hemorrhage in the glial parenchyma, note that the mononuclear inflammatory cells in the area (B) ORC; hemostatic reagent which was not resorbed within hemorrhagic area in the glial parenchyma, showing mild inflammatory reaction (C) MPH; edematous glial parenchyma showing hemorrhagic areas (focal hemorrhage) which was devoid of any foreign material (hemostatic reagent). (Hemorrhage fields are marked with "*" and parenchymal fields are marked with "\#". Arrow shows residual hemostatic material).

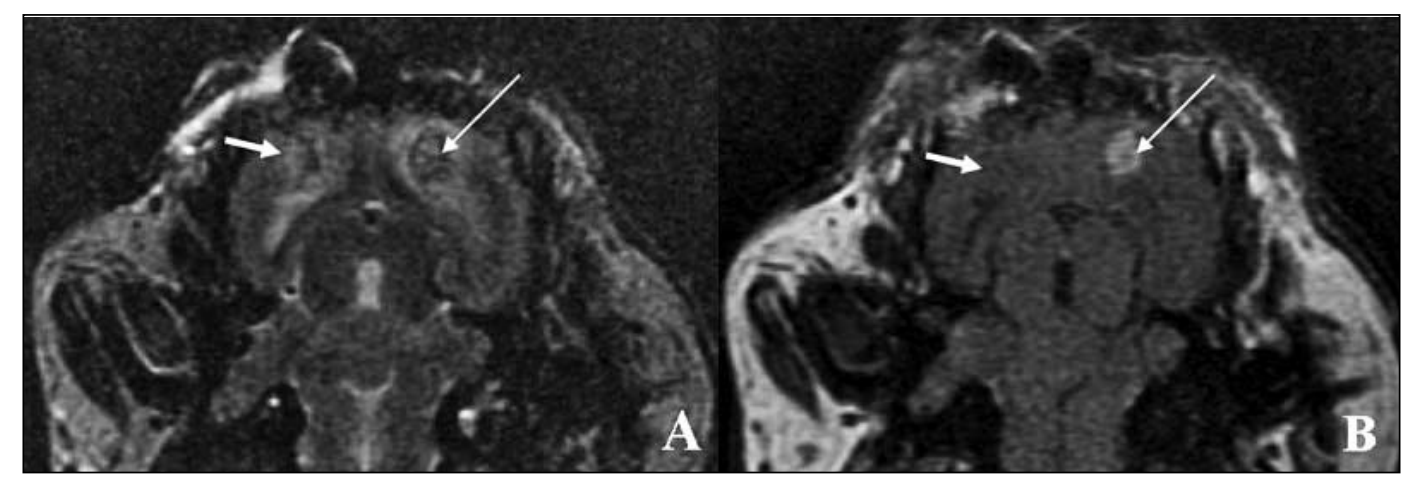

Figure 3: Coronal T2-weighted MRI (A) shows hyperintense edematous areas (arrows) in both hemispheres, operated with ORC on the right side and with MPH on the left side. On coronal T1-weighted MR image (B); although the parenchymal edema was minimally hypointense compared to brain parenchyma (thick and short arrow) on the area operated with ORC, the area operated with MPH was hyperintense (thin and long arrow), consistent with hemorrhage. In this animal the calculated volume of edema was larger on the MPH side. 


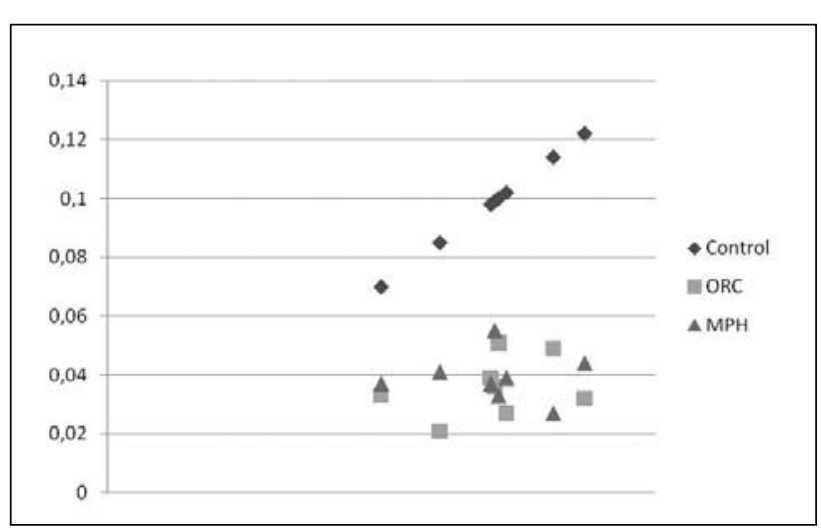

Figure 4: Graph showing the distribution of edema volumes measured on MRI within surgical fields for all groups in $\mathrm{mm}^{3}$.

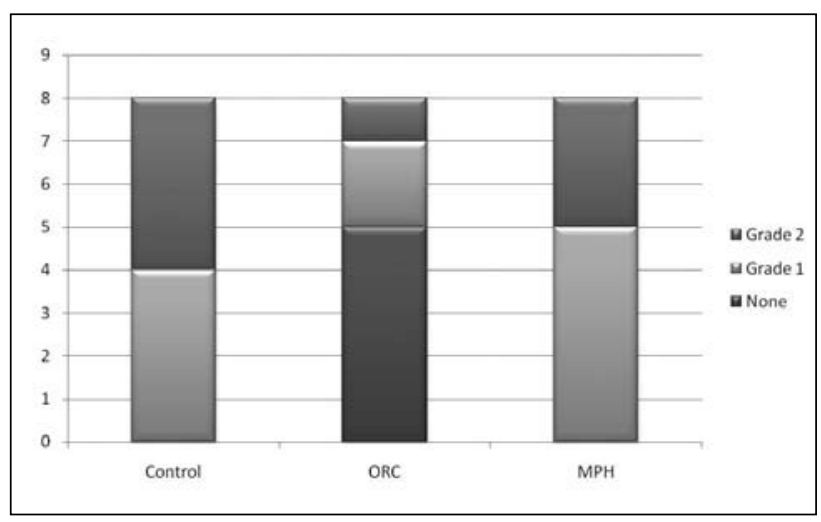

Figure 5: Graph showing the parenchymal distortion values graded as 0 (none), 1 (mild) and 2 (significant) for all groups.

in neurosurgical interventions are strong hemostatic efficacy, absence of tissue reaction or inflammation, bio-degradation capability, promotion of tissue healing, cost-effectiveness, minimal imaging artifacts and user-friendly handling $(2,18)$. Non-absorbed hemostatic materials may result in foreign body reaction, edema and thus may provide a focus for infections $(4,9)$.

Early post-operative and follow-up MRI are crucial in patients with brain tumors and true interpretation is extremely important for decision making. Topical hemostatic agents in early post-operative images and their remnants in the follow-up period may cause misinterpretation since especially collagen- and cellulose-based agents may have effects on the $\mathrm{pH}$ and $\mathrm{T} 1$ values of blood and have hyperintense signal characteristics on T1-weighted images $(9,16)$. These features may mimic a residual or recurrent tumor on post-contrast MR scans $(10,13)$. Using a topical agent with a minimal imaging artifact or which can be easily removed from the surgical field or degraded is therefore more advantageous especially in patients with brain tumors.

In this study, we compared the MR imaging features, hemostatic effects and tissue reactions of ORC and MPH within the early post-operative period in a rabbit neurosurgical model.

ORC (Oxidized regenerated cellulose) is a widely used topical hemostatic agent with accepted safety and efficacy. It was initially presented by Frantz et al. and was developed into the regenerated form in $1960(6,11,14)$. ORC is a ready to use, absorbable loose-knit mesh which provides both chemical and mechanical hemostasis (9).

MPH (Microporous polysaccharide hemospheres) is a new generation, absorbable, powder-like hemostatic agent made from plant starch. It includes microspheres that act as an absorber for fluid and small molecular components of blood and concentrates the bigger particles within the field of action by dehydration, then accelerates the fibrin mesh formation (4). Its safety and efficacy have been shown in many tissues but there is only one study evaluating MPH in the brain $(1,4,5,7,8,11)$. To the best of our knowledge, this is the first study evaluating the safety and efficacy of MPH in terms of imaging features.

Both histopathological and radiological aspects of hemostatic agents were evaluated and compared with each other and the control group in the presented study. There was no statistically significant difference between ORC and MPH groups in histopathological evaluation except slightly more inflammatory tissue reaction in the MPH group; however the amount of hemorrhage and pericellular edema was lower in both groups than in the control group. There was no significant difference in neuronal degeneration between all three groups. Measurement of edema volumes in MRI revealed no statistically significant difference between the ORC and MPH groups, however, the results were better than the control group for both of the groups $(\mathrm{p}<0.001)$. Parenchymal distortion was lower in the ORC group than MPH and the control groups in MR images. ORC and gelatin sponge have been compared by Kaymaz et al., and lower tissue reaction was found with ORC than with gelatin sponge histopathologically but MRI findings revealed less parenchymal distortion in the gelatin sponge group (9). 
Radiological findings revealed a statistically significant difference between the treatment groups and the control group in terms of edema volumes in favor of the treatment groups but there was no significant difference in edema between the groups on histopathological examination.

The irrigation of the surgical field removes the $\mathrm{MPH}$ from the brain, which is why MPH was not observed in any surgical field on histopathological examination. This is an important advantage since $\mathrm{MPH}$ probably causes less tissue reaction and less imaging artifact in long term. Hpwever, only early tissue reactions were evaluated in the presented study and inflammation was mildly higher in the $\mathrm{MPH}$ group. Residual foreign material within the surgical field is an undesirable situation in neurosurgical interventions. Minimal use of hemostatic agent for effective hemostasis and maximal cleaning of field from residual agents after achievement of hemostasis is recommended (18). The in-vitro antimicrobial activity of ORC in the early post-operative period via decreasing the local $\mathrm{pH}$ has been shown previously (15), but ORC may also cause granulation formation without bio-degradation in the late post-operative period and this may result complicate the radiological and clinical differential diagnosis of abscess, residual / recurrent tumors and granuloma $(10,12,13$, 16). Furthermore, existence of residual material may serve as a bed for microorganisms in the late period. Ereth et al, have compared floseal, ORC, avitene and $\mathrm{MPH}$ in a rat brain hemorrhage model and pointed the complete removal of hemostatic agent at postoperative $28^{\text {th }}$ day only in the MPH group. Moreover, they have observed the disappearance of MPH as early as the post-operative $6^{\text {th }}$ hour (4). In contrast to their study, we did not observe any residual $\mathrm{MPH}$ while residual ORC was seen in all subjects obviously. This difference may be explained by the different lesioning model and probably longer irrigation of the surgical fields in the presented study. In another study comparing ORC with collagen fleece in a rabbit brain hemorrhage model, ORC was absorbed later than collagen fleece (19).

Numerous studies are available in the current literature focusing on the hemostatic efficacy of ORC but limited numbers of studies are found on the novel agent $-\mathrm{MPH}$ - used in different surgical sites. Humphreys et al $(7,8)$ have found MPH to be an effective hemostatic agent in studies performed with laparoscopic trocar injuries to the kidney and spleen in pigs. Ersoy et al. have reported that MPH is effective in the hemostasis of severe femoral arterial bleeding in rats (5). Our study also suggested that both ORC and MPH have similar hemostatic effects in the rabbit brain hemorrhage model. A combination of various hemostatic agents is also in use for more effective bleeding control. Bjorses and Holst have found the combination of MPH and freeze dried fVIIa more effective than MPH or freeze dried VIIa alone in high flow-rate bleeding of the rat heparinized carotid artery (3).

Another criteria of an optimal hemostatic agent is the biocompatibility of the agent with the normal tissues and the role in the tissue healing. MPH was found to be associated less with mucosal cilia loss, inflammation and fibrosis in a study comparing $\mathrm{MPH}$ and floseal following surgical intervention to the maxillary sinus in rabbits by Antisdel et al. (1). In our study, no difference in neuronal degeneration between ORC and MPH was detected.

\section{CONCLUSION}

Hemostasis is critical in neurosurgery and the ideal topical hemostatic agent is not available yet. $\mathrm{MPH}$ (microporous polysaccharide hemospheres), a new agent, provide safe and effective hemostasis in the brain in this study. The most important advantage of MPH is its clearance after irrigation of the surgical field and having the potential of causing less imaging artifacts by this way.

\section{REFERENCES}

1. Antisdel JL, Janney CG, Long JP, Sindwani R: Hemostatic agent microporous polysaccharide hemospheres (MPH) does not affect healing or intact sinus mucosa. Laryngoscope Jul 118(7):1265-1269, 2008

2. Arand AG, Sawaya R: Intraoperative chemical hemostasis in neurosurgery. Neurosurgery 18(2):223-233, 1986

3. Björses K, Holst J: Various local hemostatic agents with different modes of action; an in vivo comparative randomized vascular surgical experimental study. Eur J Vasc Endovasc Surg 33:363-370, 2007

4. Ereth MH, Schaff M, Ericson EF, Wetjen NM, Nuttall GA, Oliver WC: Comparative safety and efficacy of topical hemostatic agents in a rat neurosurgical model. Neurosurgery 63/ONS (Suppl 2):ONS369-ONS372, 2008

5. Ersoy G, Kaynak MF, Yilmaz O, Rodoplu U, Maltepe F, Gokmen N: Hemostatic effects of microporous polysaccharide hemosphere ${ }^{\circledR}$ in a rat model with severe femoral artery bleeding. Adv Ther 24(3):485-492, 2007

6. Frantz V: Absorbable cotton, paper and gauze (oxidized cellulose). Ann Surg 118:116-126, 1943 
7. Humphreys MR, Castle EP, Andrews PE, Gettman MT, Ereth MH: Microporous polysaccharide hemospheres for management of laparoscopic trocar injury to the spleen. Am J Surg 195(1):99-103, 2008

8. Humphreys MR, Lingeman JE, Terry C, Castle EP, Andrews PE, Gettman MT, Ereth MH: Renal injury and the application of polysaccharide hemospheres: A laparoscopic experimental model. J Endourol Jun;22(6):1375-1381, 2008

9. Kaymaz M, Tokgoz N, Kardes O, Ozkose Z, Ozogul C, Orbay $\mathrm{T}$ : Radiological and histopathological examination of early tissue reactions to absorbable hemostatic agents in the rabbit brain. Journal of Clinical Neuroscience 12(4): 445-448, 2005

10. Kothbauer KF, Jallo GI, Siffert J, Jimenez E, Allen JC, Epstein FJ: Foreign body reaction to hemostatic materials mimicking recurrent brain tumor. J Neurosurg 95:503-506, 2001

11. Murat FJ, Ereth MH, Dong Y, Piedra MP, Gettman MT: Evaluation of microporous polysaccharide hemospheres as a novel hemostatic agent in open partial nephrectomy: Favorable experimental results in the porcine model. Journal of Urology 172:1119-1122, 2004

12. Oto A, Remer EM, O'Malley CM, Tkach CM, Gill IS: MR characteristics of oxidized cellulose (Surgicel). AJR 172:14811484, 1999
13. Sandhu GS, Elexpuru-Camiruaga JA, Buckley S: Oxidized cellulose (Surgicel $\AA$ ) granulomata mimicking tumour recurrence. British Journal of Neurosurgery 10(6):617-619, 1996

14. Schonauer C, Tessitore E, Barbagallo G, Albanese V, Moraci A: The use of local agents: bone wax, gelatin, collagen, oxidized cellulose. Eur Spine J 13(Suppl.1):S89-S96, 2004

15. Spangler D, Rothenburger S, Nguyen K, Jampani H, Weiss S, BhendeS: In vitro antimicrobial activity of oxidized regenerated cellulose against antibiotic-resistant microorganisms. Surg Infec (Larchmt) 4(3):255-262, 2003

16. Spiller M, Tenner MS, Couldwell WT: Effect of absorbable topical hemostatic agents on the relaxation time of blood: An in vitro study with implications for postoperative magnetic resonance imaging. J Neurosurg 95:687-693, 2001

17. Tokgoz N, Kaymaz M, Oner AY, Emmez H: Experimental MR imaging of the rabbit brain: How to perform it better. AJNR Am J Neuroradiol. 27(4):725, 2006

18. Tomizawa Y: Clinical benefits and risk analysis of topical hemostats: A review. J Artif Organs 8:137-142, 2005

19. Voormolen JH, Ringers J, Bots GT, van der Heide A, Hermans J: Hemostatic agents: Brain tissue reaction and effectiveness. A comparative animal study using collagen fleece and oxidized cellulose. Neurosurgery 20(5):702-709, 1987 